\title{
Communication
}

\section{Thermoregulated poly(ethylene glycol) biphasic system with Pd nanoparticle catalysts for selective hydrogenation of cinnamaldehyde}

\author{
NIU Mingming, WANG Yanhua*, LI Wenjiang, JIANG Jingyang, JIN Zilin \\ State Key Laboratory of Fine Chemicals, Dalian University of Technology, Dalian 116024, Liaoning, China
}

\section{A R T I C L E I N F O}

Article history:

Received 31 January 2013

Accepted 19 February 2013

Published 20 April 2013

\section{Keywords:}

Thermoregulated poly(ethylene glycol)

biphasic system

Selective hydrogenation

Palladium

Nanoparticle

Cinnamaldehyde

\begin{abstract}
A B S T R A C T
Poly(ethylene glycol) (PEG)-stabilized Pd nanoparticles were prepared by simple hydrogen reduction of $\mathrm{PdNa}_{2} \mathrm{Cl}_{4} \cdot \mathrm{xH}_{2} \mathrm{O}$ in the presence of $\mathrm{PEG}_{4000}$ (PEG with an average molecular mass of 4000 $\mathrm{g} / \mathrm{mol}$ ). These were shown to be efficient and recyclable catalysts for the selective hydrogenation of cinnamaldehyde in a thermoregulated PEG biphasic system, which allows for an efficient homogeneous catalytic reaction, easy biphasic separation and catalyst reuse. Under optimized reaction conditions, the conversion of cinnamaldehyde and the selectivity of hydrocinnamaldehyde (HCAL) were $99 \%$ and $98 \%$, respectively. The $\mathrm{PEG}_{4000}$-stabilized Pd nanoparticle catalyst could be easily separated from the product by phase separation and reused eight times without evident loss of activity and selectivity.
\end{abstract}

(c) 2013, Dalian Institute of Chemical Physics, Chinese Academy of Sciences. Published by Elsevier B.V. All rights reserved.

Over the past decades, soluble transition-metal nanoparticles in catalysts have attracted growing interest because of their highly catalytic efficiency and unique properties. However, as with traditional homogeneous catalysts, one of the main disadvantages of soluble nanoparticle catalysts is the difficulty of recovering the catalysts from the products. To overcome this problem, several strategies have been disclosed. The liquid/liquid biphasic system, i.e., aqueous/organic biphasic system [1-3], fluorous/organic biphasic system [4-6], and ionic liquid biphasic system [7-10] were most frequently used.

Recently, a thermoregulated biphasic system composed of PEG and organic solvents has been developed. This allows for a highly efficient homogeneous catalytic reaction, easy biphasic separation and catalyst reuse because of the thermoregulated phase-transition property of the system. This system has been employed for the hydroformylation of olefins and selective hydrogenation of 1,5-cyclooctadiene by applying the PEG-stabilized Rh or Pd nanoparticles to the catalysts $[11,12]$. The selective hydrogenation of cinnamaldehyde is useful as the possible products of hydrocinnamaldehyde (HCAL) or cinnamyl alcohol (COL) are used in the synthesis of fine chemicals, pharmaceuticals and fragrances. However, most studies on this transformation have concentrated on transition-metal heterogeneous catalysts or homogeneous complex catalysts [13-18]. As a continuation of previous works and to best use the thermoregulated PEG biphasic system containing soluble transition-metal nanoparticles, this study focused on PEG4000-stabilized Pd nanoparticle catalyzed selective hydrogenation of cinnamaldehyde in a thermoregulated PEG biphasic system.

\footnotetext{
*Corresponding author. Tel: +86-411-84986033; Fax: +86-411-84986033; E-mail: yhuawang@dlut.edu.cn This work was supported by the National Natural Science Foundation of China (21173031) and the Fundamental Research Funds for the Central Universities.
} 


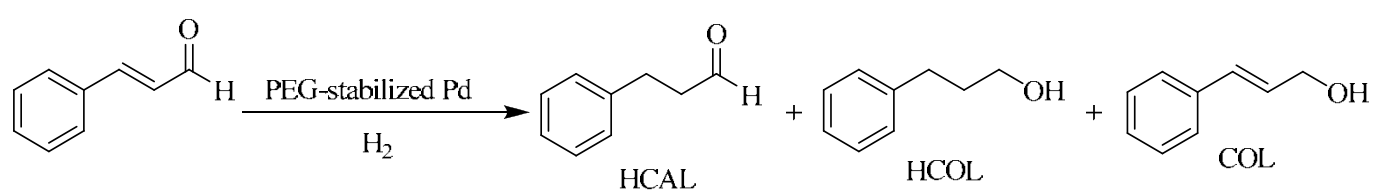

Scheme 1. Hydrogenation of cinnamaldehyde.

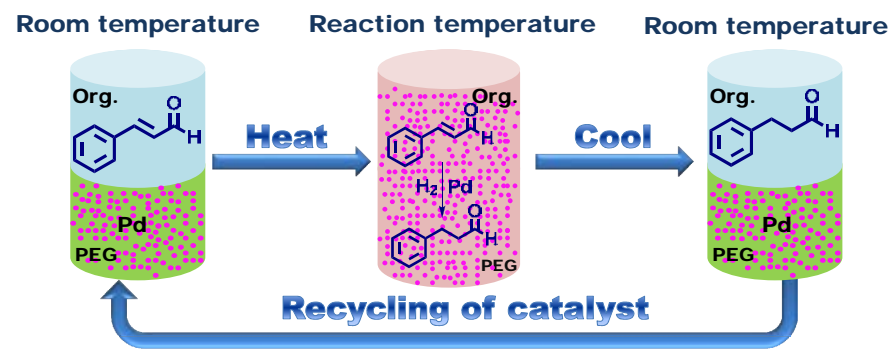

Fig. 1. Schematic illustration of $\mathrm{PEG}_{4000}$-stabilized Pd nanoparticle catalyzed selective hydrogenation of cinnamaldehyde in a thermoregulated PEG biphasic system.

Pd nanoparticles stabilized by $\mathrm{PEG}_{4000}$ were prepared. A mixture of $\mathrm{PdNa}_{2} \mathrm{Cl}_{4} \cdot x \mathrm{H}_{2} \mathrm{O}$ (containing $30 \% \mathrm{Pd}, 1.77 \mathrm{mg}, 0.005$ mmol) and PEG 4000 (2.0 g, $0.5 \mathrm{mmol}$ ) was added to a $75 \mathrm{ml}$ stainless-steel autoclave. The autoclave was flushed three times with 2.0 MPa hydrogen and stirred under hydrogen (4.0 MPa) at $70{ }^{\circ} \mathrm{C}$ for $2 \mathrm{~h}$. The reactor was then cooled to room temperature and depressurized. The PEG4000-stabilized Pd nanoparticles obtained were used for the selective hydrogenation of cinnamaldehyde.

Selective hydrogenation reactions were performed in a 75 ml stainless-steel autoclave. The PEG4000-stabilized Pd nanoparticles ( $0.005 \mathrm{mmol})$, cinnamaldehyde $(5 \mathrm{mmol})$, toluene (3.0 g), $n$-heptane $(1.0 \mathrm{~g})$ and $n$-decane $(0.2 \mathrm{~g})$ were added to the autoclave and purged three times with hydrogen at 2.0 MPa. The autoclave was then pressurized with hydrogen to the desired pressure and held at a set temperature with stirring in a thermostatic oil bath for the desired length of time. After the reaction, the autoclave was cooled to room temperature and depressurized. The upper organic phase was separated from the lower PEG phase by phase separation and analyzed by GC and GC-MS.

Gas chromatography analyses were performed on a Tianmei 7890 GC instrument (Shanghai Techcomp Instrument Ltd, Shanghai, China) equipped with a $50 \mathrm{~m}$ OV-101 column (inner diameter $0.25 \mathrm{~mm}$ ) and an FID detector ( $\mathrm{N}_{2}$ as a carrier gas). GC-MS measurements were performed on an HP 6890 GC/5973 MSD instrument (with a 30 m HP-5MS column, inner diameter $0.25 \mathrm{~mm}$; He as a carrier gas). The transmission electron microscopy (TEM) images were taken with a Tecnai $G^{2} 20$ Spirit microscope at an accelerating voltage of $120 \mathrm{kV}$ (FEI company). ICP-AES analyses of Pd were carried out on an Optima 2000 DV (Perkin Elmer, USA).

Cinnamaldehyde has two reactive sites for hydrogenation ( $\mathrm{C}=\mathrm{C}$ and $\mathrm{C}=\mathrm{O}$ bonds). Selective hydrogenation of the $\mathrm{C}=\mathrm{C}$ bond yields hydrocinnamaldehyde (HCAL), while selective hydrogenation of the $\mathrm{C}=0$ bond delivers cinnamyl alcohol (COL). If hydrogenation takes place at both $\mathrm{C}=\mathrm{C}$ and $\mathrm{C}=\mathrm{O}$ bonds, hydrocinnamyl alcohol (HCOL) will form (Scheme 1).
The schematic illustration of selective hydrogenation of cinnamaldehyde in a thermoregulated PEG biphasic system containing PEG4000-stabilized Pd nanoparticles is shown in Fig. 1. At room temperature, the lower PEG phase containing the Pd nanoparticles was immiscible with the upper organic phase consisting of toluene and $n$-heptane with the cinnamaldehyde substrate (left panel in Fig. 1). It was noted that when the temperature was elevated gradually to the reaction temperature, the biphasic system merged into a single phase and the reaction proceeded in a homogeneous phase (central panel in Fig. 1). Finally, by decreasing the temperature to room temperature after the reaction was completed, the system recovered to biphasic form (right panel in Fig. 1). The product and the catalyst were easily collected from the organic and PEG phase, respectively. The recovered catalyst can be reused without further purification or activation.

The optimal reaction conditions for $\mathrm{PEG}_{4000}$-stabilized $\mathrm{Pd}$ nanoparticle catalyzed selective hydrogenation of cinnamaldehyde in a thermoregulated PEG biphasic system were first determined. As shown in Table 1, the conversion of cinnamaldehyde increases with increasing temperature (entries 1-4). At $120^{\circ} \mathrm{C}$, the conversion of cinnamaldehyde and the selectivity of

\section{Table 1}

$\mathrm{PEG}_{4000}$-stabilized Pd nanoparticle catalyzed selective hydrogenation of cinnamaldehyde.

\begin{tabular}{ccccccc}
\hline $\begin{array}{c}\text { Entry } \\
\text { Tempera- } \\
\text { ture }\left({ }^{\circ} \mathrm{C}\right)\end{array}$ & $\begin{array}{c}\text { Pressure } \\
(\mathrm{MPa})\end{array}$ & $\begin{array}{c}\text { Time } \\
(\mathrm{h})\end{array}$ & $\begin{array}{c}\text { Conver- } \\
\text { sion (\%) }\end{array}$ & tivity (\%) & $\begin{array}{c}\text { HCOL selec- } \\
\text { tivity (\%) }\end{array}$ \\
\hline 1 & 80 & 4.0 & 7 & 36 & $>99$ & $<1$ \\
2 & 100 & 4.0 & 7 & 70 & 99 & 1 \\
3 & 110 & 4.0 & 7 & 89 & 98 & 2 \\
4 & 120 & 4.0 & 7 & 99 & 98 & 2 \\
5 & 120 & 1.0 & 7 & 70 & 97 & 3 \\
6 & 120 & 2.0 & 7 & 82 & 98 & 2 \\
7 & 120 & 3.0 & 7 & 90 & 97 & 3 \\
8 & 120 & 4.0 & 4 & 36 & 98 & 2 \\
9 & 120 & 4.0 & 5 & 70 & 97 & 3 \\
10 & 120 & 4.0 & 6 & 92 & 97 & 3 \\
\hline
\end{tabular}

Reaction conditions: $\mathrm{PEG}_{4000} 2.0 \mathrm{~g}$ (containing $5.0 \times 10^{-3} \mathrm{mmol} \mathrm{Pd}$ ), toluene $3.0 \mathrm{~g}, n$-heptane $1.0 \mathrm{~g}$, $n$-decane $0.2 \mathrm{~g}$ (internal standard), cinnamaldehyde $/ \mathrm{Pd}=1000$ (molar ratio). 


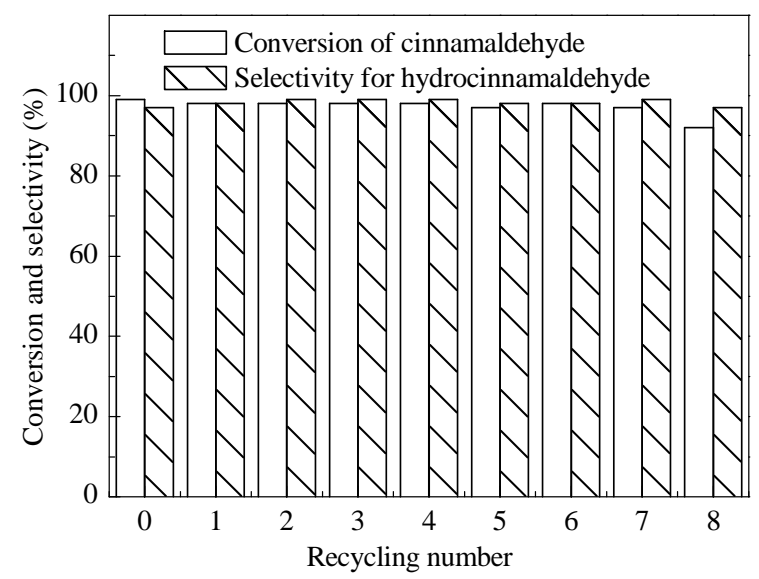

Fig. 2. Recycling efficiency of $\mathrm{PEG}_{4000}$-stabilized Pd nanoparticle catalysts for the selective hydrogenation of cinnamaldehyde.

HCAL were $99 \%$ and $98 \%$, respectively. The effects of hydrogen pressure on the reaction were studied. In the range of 1.0-4.0 $\mathrm{MPa}$, the conversion of cinnamaldehyde increased with increasing hydrogen pressure (entries 4-7). It is also evident from Table 1 (entries 4, 8-10) that prolonging reaction times led to an increased conversion of cinnamaldehyde. In all investigated cases, the selectivity of HCAL was higher than $97 \%$ and no COL was observed. Compared with previously reported Pd, $\mathrm{Rh}, \mathrm{Ru}$ or Ir catalysts [17-20], PEG4000-stabilized Pd nanoparticle catalysts in a thermoregulated PEG biphasic system are more active.

The recycling efficiency of $\mathrm{PEG}_{4000}$-stabilized Pd nanoparticle catalysts was also investigated. After the reaction, the upper organic phase was separated from the lower catalyst-containing phase by simple phase separation. The lower catalyst-containing phase was directly used in the next reaction run. Under the identical reaction conditions to entry 4 in Table 1 , the recovered Pd nanoparticles exhibited highly catalytic efficiency without evident loss of activity or selectivity after the catalyst was reused eight times (Fig. 2). TEM images of newly prepared Pd nanoparticles and after eight recycles showed a slight increase of particle size from original $(1.9 \pm 0.5) \mathrm{nm}$ to $(2.0 \pm 0.5) \mathrm{nm}$ (Fig. 3).

The leaching of transition-metal nanoparticle catalysts is a significant concern in these transformations. This paper studied Pd leaching in recycle experiments by determining the Pd content in the upper organic phase at the end of the reaction.
The leaching of Pd was detected by ICP-AES and the results indicated that the leaching of Pd was under the minimum detectable amount $(0.003 \mu \mathrm{g} / \mathrm{ml})$.

$\mathrm{PEG}_{4000}$-stabilized Pd nanoparticle catalysts in a thermoregulated PEG biphasic system were shown to be highly active, selective and recyclable for the selective hydrogenation of cinnamaldehyde towards HCAL. Considering the extensive applications of Pd nanoparticle catalysts, the thermoregulated PEG biphasic system containing PEG-stabilized Pd nanoparticles should find more uses in other catalytic reactions.

\section{References}

[1] Denicourt-Nowicki A, Ponchel A, Monflier E, Roucoux A. Dalton Trans, 2007: 5714

[2] Zahmakıran M, Özkar S. Nanoscale, 2011, 3: 3462

[3] Li K X, Wang Y H, Jiang J Y, Jin Z L. Catal Commun, 2010, 11: 542

[4] Chechik V, Crooks R M. J Am Chem Soc, 2000, 122: 1243

[5] Moreno-Mañas M, Pleixats R, Villarroya S. Organometallics, 2001, 20: 4524

[6] Tzschucke C C, Markert C, Bannwarth W, Roller S, Hebel A, Haag R. Angew Chem, Int Ed, 2002, 41: 3964

[7] Dupont J, de Souza R F, Suarez P A Z. Chem Rev, 2002, 102: 3667

[8] Mu X D, Meng J Q, Li Z Ch, Kou Y. J Am Chem Soc, 2005, 127: 9694

[9] Zeng Y, Wang Y H, Jiang J Y, Jin Z L. Catal Commun, 2012, 19: 70

[10] Zeng Y, Wang Y H, Xu Y Ch, Song Y, Zhao J Q, Jiang J Y, Jin Z L. Chin J Catal (曾艳, 王艳华, 徐贻成, 宋颖, 赵家骐, 蒋景阳, 金子林. 催化学 报), 2012, 33: 402

[11] Sun Zh, Wang Y H, Niu M M, Yi H Q, Jiang J Y, Jin Z L. Catal Commun, 2012, 27: 78

[12] Huang T S, Wang Y H, Jiang J Y, Jin Z L. Chin Chem Lett, 2008, 19: 102

[13] Kume Y, Qiao K, Tomida D, Yokoyama C. Catal Commun, 2008, 9: 369

[14] Hong Y Ch, Sun K Q, Zhang G R, Zhong R Y, Xu B Q. Chem Commun, 2011, 47: 1300

[15] Castillejos E, Jahjah M, Favier I, Orejón A, Pradel C, Teuma E, Masdeu-Bultó A M, Serp P, Gómez M. ChemCatChem, 2012, 4: 118

[16] Marchetti M, Minello F, Paganelli S, Piccolo O. Appl Catal A, 2010, 373: 76

[17] Callis N M, Thiery E, Le Bras J, Muzart J. Tetrahedron Lett, 2007, 48: 8128

[18] Morrissey S, Beadham I, Gathergood N. Green Chem, 2009, 11: 466

[19] Landaeta V R, López-Linares F, Sánchez-Delgado R, Bianchini C, Zanobini F, Peruzzini M. J Mol Catal A, 2009, 301: 1

[20] Ni X J, Zhang B S, Li Ch, Pang M, Su D Sh, Williams C T, Liang Ch H. Catal Commun, 2012, 24: 65
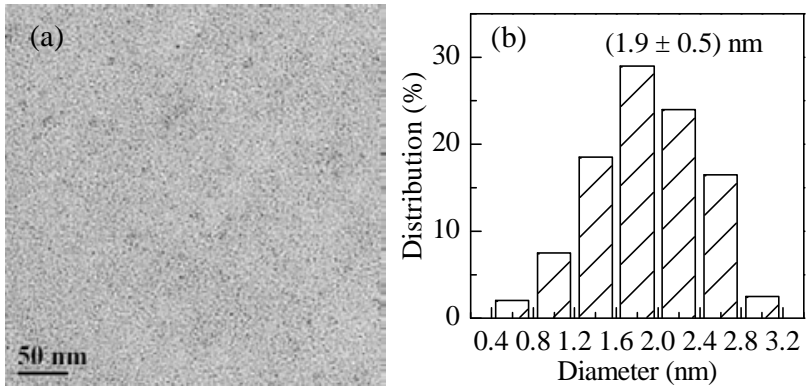

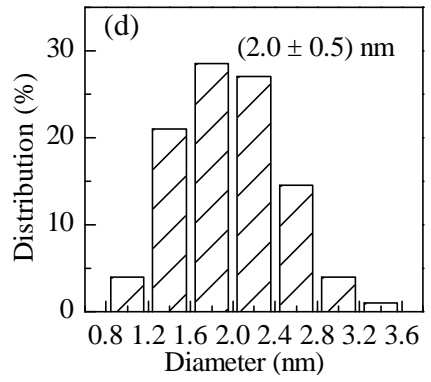

Fig. 3. TEM images (a, c) and particle size histograms (b, d) of PEG4000-stabilized Pd nanoparticles (200 particles). (a, b) Newly prepared; (c, d) After eight recycles. 


\title{
Graphical Abstract
}

Chin. J. Catal., 2013, 34: 674-678 doi: 10.1016/S1872-2067(12)60552-X

Thermoregulated poly(ethylene glycol) biphasic system with Pd nanoparticle catalysts for selective hydrogenation of cinnamaldehyde

NIU Mingming, WANG Yanhua*, LI Wenjiang, JIANG Jingyang, JIN Zilin

Dalian University of Technology

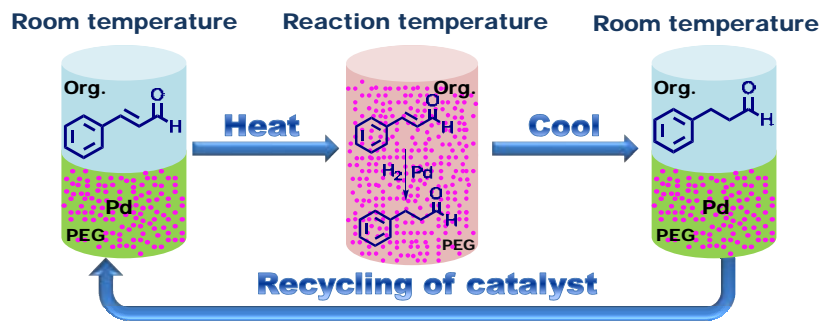

Poly(ethylene glycol)-stabilized Pd nanoparticles were demonstrated to be efficient and recyclable catalysts for the selective hydrogenation of cinnamaldehyde in a thermoregulated PEG biphasic system.

\section{温控聚乙二醇两相体系中纳米钯催化肉桂醛选择性加氢反应}

\author{
牛明铭，王艳华，李文江，蒋景阳，金子林 \\ 大连理工大学精细化工国家重点实验室, 辽宁大连116024
}

\begin{abstract}
摘要: 将具有 “高温混溶、室温分相” 功能的聚乙二醇 $4000\left(\mathrm{PEG}_{4000}\right)$ 与甲苯-正庚烷组成的两相体系用于纳米钯催化的肉桂醛选 择性加氢反应中. 在优化的反应条件下, 肉桂醛转化率和氢化肉桂醛选择性分别为 $99 \%$ 和 $98 \%$. 钯纳米催化剂经简单分相即可与 产物分离, 且循环使用8次, 其活性和选择性基本保持不变.
\end{abstract}

关键词: 温控聚乙二醇两相体系; 选择性加氢; 钯; 纳米粒子; 肉桂醛

收稿日期: 2013-01-31. 接受日期: 2013-02-19. 出版日期: 2013-04-20.

*通讯联系人. 电话/传真: (0411)84986033; 电子信箱: yhuawang@dlut.edu.cn 基金来源：国家自然科学基金(21173031); 中央高校基本科研业务费专项资金.

本文的英文电子版由Elsevier出版社在ScienceDirect上出版(http://www.sciencedirect.com/science/journal/18722067).

近年来, 可溶性过渡金属纳米催化剂因其独特高效 的催化性能而备受关注, 但与传统的均相催化剂一样, 存在催化剂与产物分离回收难的问题. 为了解决这个难 题, 液/液两相催化体系的研究引人注目, 其中主要有水/ 有机两相体系 ${ }^{[1 \sim 3]}$, 氟/有机两相体系 ${ }^{[4 \sim 6]}$ 和离子液体两相 体系 $\left.{ }^{[7} 10\right]$ 等.

最近, 本课题组以聚乙二醇(PEG)为稳定剂制备了 $\mathrm{Rh}$ 及Pd纳米催化剂, 并将其用于温控PEG两相体系中烯 烃氢甲酰化反应和1,5-环辛二烯的选择性加氢反应, 发 现该催化体系不仅具有高的催化活性, 而且具有催化剂 与产物易于分离、催化剂可循环使用的特点 ${ }^{[11,12]}$. 另外, 肉桂醛的选择性加氢产物氢化肉桂醛(HCAL)或肉桂醇 (COL)均是重要的精细化学品, 在医药及香料中有广泛 的应用. 目前, 该反应多采用过渡金属多相催化剂或均 相配合物催化剂 ${ }^{[13 ~ 18]}$. 因此, 本文以 $\mathrm{PEG}_{4000}$ 为稳定剂
制备Pd纳米催化剂, 并用于温控PEG两相体系中肉桂醛 的选择性加氢反应中, 重点考察催化剂的催化活性、选 择性及循环使用效果.

将 $\mathrm{PdNa}_{2} \mathrm{Cl}_{4} \cdot x \mathrm{H}_{2} \mathrm{O}$ (含 $30 \% \mathrm{Pd}, 1.77 \mathrm{mg}, 0.005 \mathrm{mmol}$ ) 和 $\mathrm{PEG}_{4000}(2.0 \mathrm{~g}, 0.5 \mathrm{mmol}$ )加入到 $75 \mathrm{ml}$ 的不锈钢高压釜 中, 用 $2.0 \mathrm{MPa}$ 氢气置换体系3次后, 充压至 $4.0 \mathrm{MPa}$, 在 $70{ }^{\circ} \mathrm{C}$ 搅拌反应 $2 \mathrm{~h}$, 然后取出高压釜, 冷却至室温, 泄压 开釜, 得到的Pd纳米催化剂备用.

将上述所得的Pd纳米催化剂 $(0.005 \mathrm{mmol})$ 、肉桂醛 (5 mmol)、甲苯 $(3.0 \mathrm{~g}) 、$ 正庚烷 $(1.0 \mathrm{~g})$ 和正癸烷 $(0.2 \mathrm{~g})$ 加 入到 $75 \mathrm{ml}$ 的不锈钢高压釜中. 用 $2.0 \mathrm{MPa}$ 氢气置换体系 3次后, 充至反应压力, 将高压釜置于已预先升至反应温 度的恒温油浴中, 在搅拌下反应至设定时间后, 取出高 压釜, 冷却至室温后泄压开釜, 通过简单分相取出上层 含产物的有机相进行分析. 
产物分析在上海天美科学有限公司GC-7890 II 型气 相色谱仪上进行, OV-101毛细管柱(长50 m, 内径 0.25 $\mathrm{mm}), \mathrm{FID}$ 检测器 ( $\mathrm{N}_{2}$ 作为载气). 在 HP $6890 \mathrm{GC} / 5973$ MSD型气相色谱/质谱联用仪上进行样品的定性分析, HP-5MS柱(长30 m, 内径 $0.25 \mathrm{~mm}$ ), He作为载气. 透射电 镜(TEM)照片在FEI公司Tecnai $\mathrm{G}^{2} 20$ Spirit型 $(120 \mathrm{kV})$ 仪 器上获得。采用Perkin Elmer 公司 Optima 2000 DV 型 ICP-AES仪器检测Pd的流失.

肉桂醛的选择性加氢反应可发生在 $\mathrm{C}=\mathrm{C}$ 或 $\mathrm{C}=\mathrm{O}$ 处, 若仅 $\mathrm{C}=\mathrm{C}$ 发生加氢反应, 则产物为 HCAL; 若只发生 $\mathrm{C}$ $=\mathrm{O}$ 加氢反应, 则产物为COL; 当两者同时加氢时, 产物 为氢化肉桂醇 $(\mathrm{HCOL})$, 反应如图式1所示.

在温控 $\mathrm{PEG}_{4000}$ /甲苯/正庚烷两相体系中, 以 $\mathrm{PEG}_{4000}$ 为稳定剂制得的纳米 $P d$ 催化肉桂醛选择性加氢反应过 程如图1所示. 反应前, 室温时, 下层含Pd纳米催化剂的 PEG相与上层含底物的有机相不互溶(图1, 左侧柱状图). 当加热至反应温度时, 整个体系为均相, 反应可顺利进 行(图1, 中间柱状图). 反应结束冷至室温后, 含Pd纳米 催化剂的PEG相又可从上层含产物的有机相中析出, 体 系重新变为两相(图1, 右侧柱状图). 通过简单分相即可 实现产物与催化剂的分离, 下层含催化剂的PEG相无需 处理或活化即可直接循环使用.

本文首先对温控PEG两相体系中 $P$ EG $_{4000}$ 稳定的纳 米Pd催化肉桂醛选择性加氢反应的条件进行了优化, 结
果见表1. 可以看出, 在 $80 \sim 120^{\circ} \mathrm{C}$ 范围内, 肉桂醛转化率 随着反应温度的升高而增加(实验 $1 \sim 4$ ); 至 $120^{\circ} \mathrm{C}$ 时, 肉 桂酫的转化率和 HCAL的选择性分别为 $99 \%$ 和 $98 \%$, 催 化活性高于 $\mathrm{Pd}, \mathrm{Ru}, \mathrm{Rh}$ 和Ir催化剂 ${ }^{[17 \sim 20]}$. 另外, 增大反应 压力有利于提高肉桂醛转化率(实验4 7); 延长反应时 间可增加肉桂醛转化率(实验 4,8 10). 在所考察的反应 条件下, HCAL的选择性均不低于 $97 \%$, 且在产物中未检 测到COL的生成.

为了进一步考察 $P G_{4000}$ 稳定的纳米Pd催化剂的循 环使用效果, 反应结束后, 经简单分相, 将含Pd纳米催化 剂的PEG相直接用于下一次反应, 结果见图2. 可以看 出, 在优化的反应条件下, Pd纳米催化剂可重复使用8次, 其活性和选择性基本保持不变. 图3为新鲜的和循环使 用8次后的Pd纳米催化剂的TEM照片. 由图3可见, 循环 使用8次后, Pd纳米催化剂的粒径从 $(1.9 \pm 0.5) \mathrm{nm}$ 略增至 $(2.0 \pm 0.5) \mathrm{nm}$.

考虑到过渡金属纳米催化剂在反应中通常会有流 失, 因此本文测定了反应结束后上层有机相中Pd的含量, ICP-AES检测结果表明, Pd在上层有机相中的流失低于 仪器检测下限 $(0.003 \mu \mathrm{g} / \mathrm{ml})$.

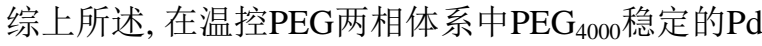
纳米催化剂在肉桂醛选择性加氢反应中表现出高的催 化活性、选择性和良好的循环使用效果, 预期该催化体 系可用于其它的催化反应中. 